piano, evidently serve for excitation of different sensations of tone. The organ of hearing of the Acridia is then, simple, in a similar sense to that of the simple eyes which perceive light, but not colours and forms ; and therefore it closely approximates to the organs of touch, which likewise render sensible simple mechanical stimuli, and are often arranged in a way similar to those organs of hearing.

'The eye of the leech consists of a cup-like inflexion of the skin, which is so lined with large transparent cells that only a narrow axial canal remains. The nerve-stem which enters at the bottom of the cup, fills this canal up to a certain height, and ends there with a ganglion, while the nerve-fibres pass into small cells, whose outer end runs out into a short rod ; the entire cup is coated round with a pigment skin and enveloped in muscles, which are directed partly parallel, partly at right angles to the skin surface, and therefore can draw the whole cup with its sheath inwards, or press the contents somewhat outwards. The former happens when the animal is surprised by sudden light, just as we close our eyes in like circumstances. After some time, the leech opens its eyes, a part of the glass-like cells on the rim of the open cup being pressed out in form of a compact hemisphere. In this way a pretty perfect visual apparatus is arranged. The outer glass.like hemisphere corresponds to the lightrefracting medium of a more perfect eye. The mosaic of rod-cells behind receives the separate rays and conveys the stimulus to the nerves, while the pigment layer cuts off all round the light that has penetrated. Besides these eyes on the upper lip, the leech possesses on other parts of the body organs constructed quite similarly, only without a pigment skin, so that they cannot be visual organs. On the other hand, they are thrust out when the animal is feeling about, and are thus evidently organs of touch; but at the same time the organs of sight are used in the same way; and when the animal sucks in the liquids agreeable to it, it draws the upper lip with the open organs of sight into the mouth. It would appear, then, that these organs are at once the means of sensations of touch, taste, and sight. To conceive this rightly we must consider that in the lowest animals the special sensations of sense are not yet differentiated; their body is in all parts alike sensitive, and sensation can only mean, quite generally, ease or uneasiness. In a higher form of organisation, certain body-parts are, by peculiar arrangements, rendered sensitive to pressure, heat, light, and chemical stimulation. But before such a simple organ of sense develops in one direction for a particular kind of stimulus, it can also communicate simple sensations of a different kind. We ourselves know such a combination of different sensations through the same organ of sense; e.g. our ear, at the boundary of the toneconductors, may feel, instead of tones, simply a vibration or a tickling, and thus has a sensation of touch like that produced in a finger-point when a vibrating tuning-fork is applied to it. Again, in our tongue, sensations of taste, smell, and touch are mixed together. Thus the organ of hearing of Acridia, which can only feel hissing noises, but no tones, may be compared, in the quality of its sensation, to an organ of touch; and of the visual organ of the leech, it may perhaps be said that it receives somewhat of the sensation of touch and taste. In short, Ranke holds these organs to be of such a kind that the general feeling is not yet fully separated into the categories of touch, hearing, seeing, \&c.

The ear of the Pterotrachea had long been known as a bladder, on whose inner wall are tuits of hair, the motions of which throw to and fro the otoliths or small spherical stones freely suspended within the bladder. It was believed that these continuous motions were connected with the sensation of hearing. Ranke proves, however, that they are merely due to convulsive movements of the animal in dying under the observation, and that the acoustical apparatus proper consists of a ganglion in the bladder wall, organised similarly to that in the Acridia. In the normal condition, the otoliths are pressed by the surrounding hair-tufts against the acoustical apparatus only in the case of stronger sound-stimuli, and they have then a damping action.

\section{NOTES FROM THE "CHALLENGER"}

PROF. THOMSON in this paper after briefly referring to a follows :-

In the section between Hawail and Tahiti, except at one station close to Tahiti, where the depth was I, 525 fathoms, the depth ranged throughout the section from 2,000 to 3,000 fathoms with a mean of about 2,600 fathoms, and the nature of the bottom was very uniform. Except in the neighbourhood of the groups of volcanic islands, where it was found to be largely composed of volcanic débris and shore mud, it consisted mainly of red clay, in many of the soundings containing a large admixture of the decaying shells of Foraminifera, and in almost all including a large proportion of manganese peroxide in the form of concretions from the size of a nut to that of an Orbulina, and passing into fine, almost microscopic granules visible under a low power in every sample of sounding. In two patches the siliceous skeletons of Radiolarians were so abundant as almost to entitle the deposit to the name of "Radiolarian ooze" and a patch between these, nearly halfway between Hawaii and Tahiti, in its abundance of surface Foraminifera approached a true "Globi. gerina ooze." The larger samples of bottom brought up in the dredge or trawl had of course generally the same character as the contents of the "Bailic" sounding-tubes; but in these large manganese concretions, up to the size of an orange, or even larger, were collected in quantity, the greater part of the red clay being usually washed out.

The surface-temperature naturally rose in passing southwards from Hawaii towards the equator, and again sank from the equa. torial belt towards Tahiti. The isothermobaths ${ }^{2}$ between $14^{\circ} \mathrm{C}$. and $24^{\circ} \mathrm{C}$. gathered together and approached much nearer to the surface in the region of the trade-winds, owing no doubt to the rapid removal to the hot surface-water by eqaporation and the driving action of the wind. Thus the isothermobathic line of $14^{\circ} \mathrm{C}$., which is at a depth of 200 fathoms a little to the north of Tahiti, is at a depth of 100 fathoms on the line. In the Atlantic all the isothermobaths seem to participate in the rise in the region of the trade-winds; it is not so in the Pacific; the lines below $14^{\circ} \mathrm{C}$. tuniformly sink, forming a depression which extends from lat. $10^{\circ} \mathrm{N}$. to lat. $10^{\circ} \mathrm{S}$.; thus the isothermobath of $5^{\circ} \mathrm{C}$, which may be taken as a type of these deeper lines, is found in lat. $10^{\circ} \mathrm{N}$. at a depth of $45^{\circ}$ fathoms; and in lat. $10^{\circ} \mathrm{S}$. at the same temperature within the limits of error of observation, while in lat. $2^{\circ} 34^{\prime} \mathrm{N}$. it is found at 625 fathoms. The point where the isothermobaths gather together most markedly and approach nearest to the surface is a little to the north of the northern border of the equatorial counter current. This fall of temperature is so decided as to indicate some special areas of cold water; and it may possibly be to some extent due to the pressing up of deeper and therefore colder layers of the colder trade-current against the hot stream. In the equatorial region between lat. $10^{\circ} \mathrm{N}$. and $10^{\circ} \mathrm{S}$. there is a belt of vater about 80 fathoms in thickness at a temperature generally over $25^{\circ} \mathrm{C}$, and the whole of this water, with the exception of the narrow band of the counter current, is running to the westward at the rate of from forty to seventy miles a day.

The bottom fauna over the whole of the manganese area is very meagre, both as to number of species and number of individuals.

After a week's stay at Tahiti the Challenger left the harbour of Papeete on the 3 rd of October, and arrived at Valparaiso on the igth.

I "Preliminary Report to the Hydrographer to the Admiralty, on some of the Results of the Cruise of H.M.S. Challenger between Hawaii and" Valparaiso, by Prof. Wyville Thomson, F.R.S., Director of the Civilian Scientific Staff on board. Paper read before the Royal Society.

lines passing I sotherm having been hitherto so specially appropriated to earth, I have found it convenient in temperature on the suriace of the earth, I have found it convenient, in considering these questions of ocean former to in, to use the terms Isothemobath and Isobathytherm; the verto through points of equal tersperature in vertical section, and the latter a line drawn through points of equal depth at which a given temperature occurs. Isothermobaths are shown in a scheme jected on the surface of the globe. II. Isobathytherms are of course pro-
jertical section, such as Plate 
The section from Papeete to Valparaiso (Plate III.) is about 5,000 miles in length, and is naturally divided into two parts, the run southwards to the parallel of $40^{\circ} \mathrm{S}$, and the course along that parallel towards Valparaiso.

Setting aside Station 279 in 680 fathoms close to Tahiti, the mean depth throughout the section was 2, I39 fathoms, con. siderably less than that of the meridional section from Honolulu to T'ahiti, and very much less than that of the section in the North Pacific, between Japan and San Francisco. The nature of the bottom is very much the same as in the meridional section, red clay imbedding nodules, and lumps of various sizes of manganese peroxide, and passing in the shallower soundings into more or less pure Globigerina ooze, and as in the section between Hawail and Tahiti the fauna is generally meagre. The trawling between Juan Fernandez and Valparaiso. (Station 298) was particularly interesting; animal forms were much more abundant than they usually are in the Pacific; and the general character of the assemblage resembled in a remarkable degree that of the fauna of the Southern Sea in the neighbourhood of the Crozets and Kerguelen, many of the species, including some singular Urchin of the family Ananchytidx, being identical. The bottom at this station was a bluish mud, the surface layer containing little or no carbonate of lime, and curiously enough a deeper layer, with a considerable proportion of Globigerina shells. There was no considerable guantity of manganese in the sounding. Notwithstanding the considerable depth of 2,225 fathoms, the conditions in this locality seem much more favourable to animal life than even the manganese area; and $\mathrm{I}$ am inclined to think that we had struck upon one of the highways by which migration takes place to the northward from the Southern Sea

A.lthough there are certain points which have yet to be worked out in detail, the general distribution of temperature in the Pacife seems sufficiently simple. In the first place, the whole mass of water consists of two well-manked divisions, an upper layer of ro great depth, in which there is rapid cooling from the surface downwards, and considerable variation in temperature in different localities; and a mass of water of incomparably greater amount, which extends to the bottom, and which may be said to have nearly the same temperature thronghout. These two divisions shade into one another, but the isothermobath of $5^{\circ} \mathrm{C}$. may be taken as indicating generally the limit between them; below this line the isothermobaths are still affected by surface thermal conditions, but comparatively slightly. Above the line of $5^{\circ} \mathrm{C}$, the course of the isothermobaths is to all appearance entirely regulated by causes affecting the surface-temperature, that is to say directly or indirectly by surface currents produced by permament, periodic, or variable winds. The equatorial current occupies the region of the trade-winds, approximately from lat. $20^{\circ} \mathrm{N}$. to $20^{\circ} \mathrm{S}$, and there is a strong but narrow counter current entirely comparable with the counter current in the Atlantic between the parallels of $5^{\circ}$ and $8^{\circ} \mathrm{N}$. The water of the equatorial current has no free egress to the westward, being intercepted by the peninsula of Malacca and the islands of the Malay archipelago; but neither is it completely arrested, as the equatorial current is in the Atlantic by the unbroken coast of America ; consequently a return current less permanent and less defined than the return current in the Atlantic finds its way to the north-eastward along the coast of Japan. The course of the Japan current is much the same as that of the Gulf-stream, and is due, as in the Atlantic return current, to the high initial velocity of the intercepted water; its influence on the temperature of the ocean is, however, much sooner reduced and obliterated.

The hot water of the Pacific equatorial current, instead of being gathered together and focussed by the form of the landbarrier, as it is in that of the Atlantic, spreads out in the middle and West Pacific in a vast sheet of abnormally warm water, extending to a depth of nearly 100 fathoms ; thus the isobathytherm of $25^{\circ} \mathrm{C}$, at 80 fathoms passes near Hawaii and Tahiti, and near the parallel of $20^{\circ} \mathrm{N}$. on sections between the Admiralty Islands and Japan. The lower isothermobaths of the upper layer are a little nearer the surface in lat. $40^{\circ} \mathrm{N}$. than in lat. $40^{\circ} \mathrm{S}$; and this I believe to be due to the banking of the Antarctic indraught against the Arctic land-barrier, and to be the only case in which the position of the lines of equal temperature in the upper layer is not absolutely dependent upon the wind.

The temperature of the underlying cold water is derived from another source, and its distribution is governed by other laws. Throughout the Pacific the isothermobath of $5^{\circ} \mathrm{C}$. maintains on the whole a very even course, oscillating between the 400 and 500-fathom lines. These oscillations depend upon causes acting on the surface, for the line rises and falls in harmony with the higher isothermobaths. The line of $5^{\circ}$. deviates sensibly on two occasions from its comparatively straight course. In the equatorial region it sinks to a depth of 625 fathoms, probably from the communication of heat from the upper layer of water by mixing; and in lat. 40 it rises to 300 fathoms, probably, as I have already said, from the accumulation of cold water against the Arctic barrier. The next three degrees of temperature are lost with increasing slowness in the next 700 fathoms, the line of $2^{\circ} \mathrm{C}$. making a very even course at a depth of 1, IOO fathoms, and the remaining degree or degrees and a fraction is lost between r, roo faihoms and the bottom. The depth of the Pacific increases slowly from the south to the north, the mean difference between the depth of the South Pacific and that of the north being perhaps as much as I,000 fathoms. Notwithstanding this increase in depth, we have satisfied ourselves, although the determination is one of great difficulty, that the bottom temperature rises slightly from the south northwards. We can scarcely say more than that it rises slightly, for the differences in the temperatures below 1,500 fathoms are so small that a result can only be arrived at by a careful combination and comparison of many observations, taking into full considera. tion the errors of the thermometers arising from all sources. There is a like very slight decrease in the bottom-temperatures from east to west.

I think we can scarcely doubt that like the similar mass of cold bottom water in the Atlantic, the botrom water of the Pacific is an extremely slow indraught from the Southern Sea. That it is moving, and moving from a cold source, is evident from the fact that it is much colder than the mean winter tem. perature of the area which it occupies, and colder than the mean winter temperature of the crust of the earth; that it is moving in one mass from the southward is shown by the uniformity of its conditions, by the gradual rise of the bottom-temperaiures to the northward, and by the fact that there is no adequate northern source of such a body of water, Behring's Strait being only forty fathoms deep, and a considerable part of that area being occupied by a warm current from the Pacific into the Arctic Sea, and by our knowledge frum observations that one or two trifling currents from the Sea of Okotsk and the Behring Sea, which are readily detected and localised, and are quite independent of the main mass of cold water, represent the only Arctic influx. During its progress northwards the upper portion of the mass becomes slightly raised in temperature by mixture with, and possibly by slow conduction from, the upper layers which are affected by solar heat. At the end of the Gulf, that is to say in the extreme north, furthest from the cold source, the temperature is, as I have already pointed out, influenced to the very bottom; and the isothermobaths between $8^{\circ}$ and $5^{\circ} \mathrm{C}$. are obviousiy raised and pressed together, probably by the accumulation of the cold water against the land. The colder bottom-water to the westward might be expected from the lower initial velocity of the Antarctic water causing it to drag against the west coast

I am every day more fully satistied that this influx of cold water into the Pacific and Atlantic oceans from the southward is to be referred to the simplest and most obvious of all causes, the excess of evaporation over precipitation in the northern portion of the land hemisphere, and the excess of precipitation over evaporation in the middle and southern part of the waterhemisphere.

After what I have already said I need scarcely add that I have never seen, whether in the Atlantic, the Southern Sea, or the Pacific, the slightest ground for supposing that such a thing exists as a general vertical circulation of the water of the ocean depending upon differences of specific gravity.

\section{NOTES}

THE forty-seventh anniversary of the Zoological Society was held on Saturday last, Viscount Walden, F.R.S., the President, being in the chair. Mr. P. L. Sclater, F.R.S., the Secretary, read the report, which showed that the income $(28,738$.) was greater than it had been in any previous year since the foundation of the Society. The total number of visitors in 1875 had been 699,918 . The new lion house had been, as far as its main portions were concerned, completed and opened to the public. The building contains fourteen dens, the 